UDC 343.71(497.11)"13"

340.15(497.11)"13"

CERIF: S149, H220, H300

DOI: 10.51204/HLH_20104A

\title{
Андреј ЦОНФАЛОНИЕРИ*
}

\section{РАЗБОЈНИШТВО У ДУШАНОВОМ ЗАКОНИКУ}

Душанов законик из 1349. іолине саяржи само јеgну оgреgбу о разбојнишитву, јер је ово кривично вело реіулисала Скраћена синйаіма Майије Властиара, йа је законоgаваи, смайрао gа није йоиребно йройисиване нових оgреgби. Ийак, у gойунама из 1354. иосвећена је велика йажна борби йройив разбојника и лойова. Разбојници ухваћени на делу су кажнавани смрћу, а они који нису ухваћени на делу ілобом. У случају неgостиаика доказа, био је ӣреgвиђен йосебан облик божјеі суgа, иравgане железом. Село је било колекииивно оgі̄oворно у случају скривана разбојника, у случају наношења шичеие йуйнику услеg неизвршень оужностии чуваюа йуиевва и у случају крађе иаревих свиюа.

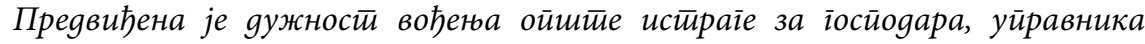
властетинстиава и стиарешине, а они би били кажнавани као разбојници у случају немара и неизвриавана йе обавезе. Увеgено је више оgреgаба за заш-

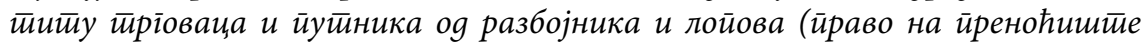

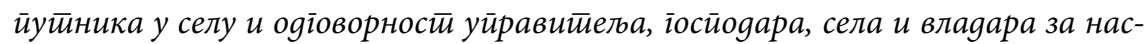

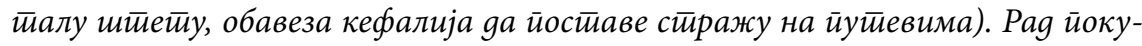
шава gа објасни факйоре који су утиицали на йежину кажнавана за разбој-

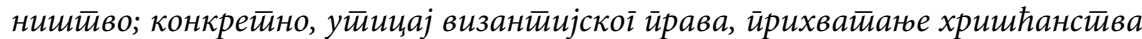

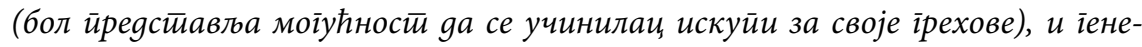
рално-йревениичвну сврху казне.

Кључне речи: Разбојнишйво. - Душанов законик.- Колекииивна оgі̄оворности. - Смрйна казна. - Среgюовековна Србија.

Аутор је студент друге године на основним академским студијама на Правном факултету Универзитета у Београду, andrej.confalonieri@gmail.com 


\section{1. УВОД}

Људској заједници је од давнина познато противправно одузимање туђе имовине с намером присвајања, односно крађа у свим својим облицима. ${ }^{1}$ Настанком приватне својине јавила су се и кривична дела против имовине, ${ }^{2}$ због чега сваки правни поредак предвиђа норме којима се имовина штити. Већ се у првим законицима старог света могу препознати казнене одредбе за лопове и разбојнике. Наиме, разбојништво је кривично дело које је кажњавано у свим правним порецима кроз историју, зато што представља зло само по себи (mala in se), па је „врло мало подложно променама с обзиром на историјски период“.3 Једино што се мења јесте предвиђена санкција за учиниоца овог кривичног дела. С обзиром на различите казне, може се рећи да је „карактеристика својствена кривичном праву велика разноликост казни прописаних за исто кривично дело у различитим историјским периодима“" 4

Значај сопствене имовине у почетку није био велики, јер је доминантни облик својине био колективна својина, ${ }^{5}$ па је за кривично дело разбојништва често било прописано гоњење по приватној туж-

1 Примера ради, у римском праву се није правила разлика између крађе и разбојништва (rapina) до првог века пре нове ере, док се касније rapina састојала у одузимању туђе покретне ствари уз примену силе да би се прибавила имовинска корист. Морала је постојати свест учиниоца да ствар припада другом лицу. Оштећеном је заштита била пружана кроз две тужбе: actio vi bonorum raptorum, односно специфичне тужбе против разбојника којом је оштећени наплаћивао четвороструку вредност ствари од сваког учесника у разбојништву и actio furti, односно тужба против лопова. Bernard S. Jackson, „Some comparative legal history: robbery and brigandage", Georgia Journal of International and Comparative Law, Vol. 1, 1/1970, 61; Ferdinand Mackeldey, Manuale di diritto romano contenente la teoria delle istitute preceduto da una introduzione allo studio del diritto romano, Prima traduzione italiana, Tipografia Pacini, Cardinali e C., R. Biblioteca di Cremona 1843, 304-307; Жика Бујуклић, Римско ирриватино йраво, Универзитет у Београду - Правни факултет, Београд 2017, 419.

2 Зоран Стојановић, Наташа Делић, Кривично йраво, Посебни gео (шесто допуњено издање), Правна књига, Београд 2019, 125.

3 Зоран Стојановић, Кривично ӣраво, Ойшӣu gео (двадесет шесто допуњено издање), Правна књига, Београд 2019, 193.

4 „A noteworthy feature of criminal law is the great variety of penalties provided at different times for the same offence“. Carl Ludwig von Bar et al., A History of Continental Criminal Law, Translated by Thomas S. Bell et al., The Continental Legal History Series., Little, Brown and Company, Boston, Massachusetts, US. 1916, Introduction by Edwin R. Keedy, I.

5 Вид. Dragomir Stojčević, „Gens, Consortium, Familia“, Studi in onore di Edoardo Volterra, Vol. 1, Milano 1971, 425-437; Сима Аврамовић, Војислав Станимиро- 
би, односно овај деликт је тад сматран приватним деликтом. ${ }^{6}$ Међутим, временом је значај приватне својине почео да расте па је ово кривично дело прерасло у јавни деликт који се гони по службеној дужности. Штавише, данас се кривично дело разбојништва сматра једним од најтежих („опасних“) ${ }^{7}$ кривичних дела и за њега су прописане строге казне, јер се њиме, поред имовине, напада и личност. То га чини не само имовинским, него и насилничким кривичним делом ${ }^{8}$ које се и данас често извршава у пракси. ${ }^{9}$

С обзиром на наведено, сматрамо оправданим изучавање начина регулисања кривичног дела разбојништва у прошлости, јер „сваки друштвени феномен заслужује да буде размотрен и са историјског аспекта". 10 Такође, како каже Ричард Поснер (Richard Posner), „од свих професија, право се највише оријентише према историји“. 11 Отуда је оправдано проучавати правну историју јер се тако долази до сазнања о садашњим правним институтима. Другим речима, „историја помаже да разумемо садашњост и у ненормативном смислу“, 12 а познавање прошлости омогућава доношење бољих

вић, Уӣopegна йравна тираgиција, Универзитет у Београду - Правни факултет, Београд 2018, 70 и даље.

6 То је нпр. учињено у атинском и у римском праву до 76. године пре нове ере. Вид. С. Аврамовић, В. Станимировић, 123; В. Jackson, 61. Упор. Ж. Бујуклић, 419.

7 Милан Шкулић, „Англосаксонска доктрина „одбране замка“ у кривичном праву САД и њене могуће рефлексије на нужну одбрану у српском кривичном законодавству“, Ђорђе Игњатовић (ур.), Казнена реакција у Србији, VII део, Универзитет у Београду - Правни факултет, Београд 2017, 61.

8 Јасмина Играчки, „Кривичноправни и криминолошки аспекти насиља и насил-

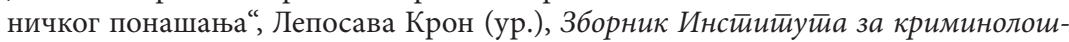
ка и социолошка истираживаюа, Година XXXIII/2014, Број 1, Институт за криминолошка и социолошка истраживања, Београд 2014, 140-141.

9 Разбојништво је најчешће извршено насилничко кривично дело у Србији. Вид. Marina M. Simović, Dragan Jovašević, „Imovinska krivična djela sa elementima nasilja i organizovanog kriminaliteta", Miodrag N. Simović (ur.), Krivično zakonodavstvo i funkcionisanje pravne države, Srpsko udruženje za krivičnopravnu teoriju i praksu / Grad Trebinje / Ministarstvo pravde Republike Srpske, Trebinje 2018, 198-199.

10 Александар Стевановић, „Утицај економских фактора на настанак и развој организованог криминалитета“, Бранислава Кнежић, Ивана Стевановић, Јанко Међедовић (ур.), Зборник Инстиитиуйа за криминолошка и социолошка истираживань, Година XXXVIII/2019, Број 1, Институт за криминолошка и социолошка истраживања, Београд 2019, 114.

11 "Law is the most historically oriented... of the professions“. Jonathan Rose, „Studying the Past: the Nature and Development of Legal History as an Academic Discipline“, The Journal of Legal History, Vol. 31, 2/2010, 101-128.

12 „History helps us understand the present... in a nonnormative... manner“. Ibid. 
прописа у будућности. Проучавати разбојништво у Душановом законику као једном од најзначајнијих српских средњовековних правних споменика, релевантно је из неколико разлога. Пре свега, начин регулисања разбојништва у Душановом законику био је од утицаја на потоње српско право, па се нпр. смртна казна за тешке случајеве разбојништва задржала у Србији све до 2002. године. ${ }^{13}$ Даље, помоћу одредаба о разбојништву се могу схватити проблеми са којима се суочавала српска средњовековна држава. Оне указују на то да није постојала разграната државна управа. Због тога се могу приметити различите врсте колективне одговорности села за скривање разбојника и обавеза господара да воде општу истрагу против разбојника и лопова. Напослетку, у српској држави вршење разбојништва међу различитим сталежима реметило је социјалне односе, због чега се вршење овог дела кажњавало без обзира на сталешку припадност. Зато се разбојништво може проучавати као изузетак од уобичајеног прописивања различитих норми или казни за властелу и ниже сталеже. Уже теме којима се рад бави јесу начин уређења кривичног дела разбојништва у Душановом законику и казнена политика за то дело, као и разлози њеног заступања.

\section{2. РАЗБОЈНИШТВО ПРЕ ДУШАНОВОГ ЗАКОНИКА}

У српском праву је разбојништво било познато и пре доношења Душановог законика. Уобичајен назив за разбојништво јесте iуca. Тај термин се среће нпр. у хрисовуљи Хиландару (1276-1281) и у уговорима са Дубровником из 1281. и 1349. године. Разбојник је био їсар. У хрисовуљи св. Николи Мрачком из 1330. године користи се термин разбој. ${ }^{14}$

Сви разбојници су називани гусарима у почетку, док је касније појам гусара сужен и почео је да се користи само за одређене категорије делинквената (за морске разбојнике, пресретаче и нападаче на бродове, и за пљачкаше трговаца на бродовима и обалских насеља). ${ }^{15}$ Разбојништвом је сматрана свака крађа извршена силом или пре-

13 3. Стојановић, „Систем казни у кривичном праву Србије и потреба његовог даљег усавршавања“, Ђ. Игњатовић (ур.), Казнена реакција у Србији, V део, Београд 2015, 2, фн. 2.

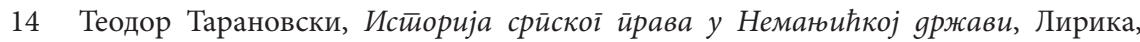
2002, 351.

15 Ђорђе Ђекић, „Гусари“, Сима Ћирковић, Раде Михаљчић (ур.), Лексикон срӣскої Среgюеї века (ЛССВ), Београд 1999, 135-136. 
тњом, што чини ово дело кривичним делом и против слободе и против имовине. ${ }^{16}$ То значи да је тада, исто као и данас, ${ }^{17}$ кривично дело разбојништва схватано као сложено кривично дело које се састоји од крађе и принуде.

Синтагма Матије Властара садржи одредбе о разбојништву у глави 12. слова А, а у глави 23. слова К говори о крађи и разбојништву. Властар је успео да разграничи ова два кривична дела према томе да ли се дело врши тајно (крађа) или употребом силе, коришћењем оружја или без оружја (разбојништво). Прописана казна за разбојнике и за оне који би уз коришћење оружја напали кућу или село јесте смртна казна на месту извршења дела (одсецање главе). ${ }^{18}$

16 Александар Соловјев, Законоgавстиво Сиеефана Душана, Цара Срба и Грка, Београдски универзитет - Правни факултет, Београд 1928, 197. И данас влада овакво схватање. Наиме, кривично дело разбојништва се може посматрати двојако. Према врсти објекта заштите (имовина, имовинска права и интереси другог лица) ово кривично дело се може сврстати у имовинска кривична дела, док се према начину и средству предузимања радње извршења може сврстати у насилничка кривична дела, која су управљена против живота и телесног интегритета, односно слободе располагања другог лица. Ј. Играчки, 140-141.

17 Вид. 3. Стојановић, Н. Делић, 138-142.

18 „Познати разбојници да се разапињу на местима где су извршили преступ, да би се таквим призором заплашили они који би тако нешто могли да предузму, и да то буде утеха сродницима убијених. Они који секу дрвеће и лозу кажњавају се као разбојници; ако више њих сече исто дрво, сваки од њих крив је као да је сам посекао цело (дрво), а ако пориче, да плати двоструку цену, ако призна, једноструку. Ако неко узима украдену ствар, биће саучесник преступнику и казниће се једнако као и он. Лопов је и онај ко тајно и без оружја врши преступ, па се не кажњава ни одсецањем уда, нити смрћу. Онај ко врши насилан преступ са оружјем, или без оружја, у којем год да је месту, кажњава се по закону“ (слово К, глава 23). „Онога ко пљачка после пожара или бродолома или у срушеној кући, закон осуђује да надокнади четвороструку цену унутар једне године, а пошто прође годину дана, да плати једноструку вредност. Исто важи и за онога ко у злој намери ово (то јест опљачкане ствари) прима. (Закон) не прихвата пљачкаше који и пре осуде враћају опљачкано, него их осуђује да плате четвороструку вредност. Ако неко силом отме покретне ствари, у оквиру једне године, уколико се потврди количина и изглед ствари, плаћа четвороструку вредност; ако се сазна за насилну отмицу, а сведоци не препознају украдено, онај који је претрпео насилну отмицу даје изјаву под заклетвом и добија од крадљивца суму једнаку изјављеној вредности украдене имовине. Они који са оружјем нападну и разарају туђе домове или њиве кажњавају се смртном казном“ (слово А, глава 12). Наведено према: Матија Властар, Синйаїма (са српскословенског језика превела Татјана Суботин-Голубовић), Српска академија наука и уметности, Београд 2013. 


\section{3. РАЗБОЈНИШТВО У ДУШАНОВОМ ЗАКОНИКУ}

\section{1. Разбојништво у Душановом законику из 1349. године}

С обзиром на чињеницу да је разбојништво исцрпно регулисано у Скраћеној синтагми, на сабору одржаном 1349. године у Серу, заступано је становиште да су се против разбојника могле користити управо одредбе о разбојништву које су биле прописане у Скраћеној синтагми и да није било потребе да се изнова пропишу. ${ }^{19}$ Ипак, у Душановом законику из 1349. године нису у потпуности изостављене норме у којима се спомиње ово кривично дело, јер се оно помиње у једном члану: „Градска земља, што је около града, што се на њој отме или украде, да плати све то околина“ (чл. 126). ${ }^{20}$ Прописана је колективна одговорност села чије би се површине граничиле са градском за штету коју су разбојници учинили. ${ }^{21}$ Одговорност села је долазила у обзир само у случају да се није нашао кривац.22

\section{2. Разбојништво у Душановом законику после допуна из 1354. године}

С обзиром на чињеницу да се схватање заступано на сабору 1349. године није показало ефикасним, донета је одлука да се посвети велика пажња борби против разбојника и лопова у допуни Душановог законика 1354. године. Наиме, донете су нове одредбе које су биле оштрије и исцрпније. ${ }^{23}$

Први члан који говори о разбојништву јесте чл. 143: „И ако се нађе разбојник, који прође кроз област крајишника, и пљачка где год и опет се врати с пленом, да плаћа крајишник седмоструко“. 24

19 А. Соловјев, Законояавстиво, 198.

20 Чланови наведени према: Никола Радојчић (прир.), Законик Цара Сиеебана и Душана 1349. и 1354, Српска академија наука и уметности, Београд 1960.

21 Ђорђе Бубало (прир.), Душанов законик, Завод за уџбенике / Службени гласник, Београд 2010, 204.

22 Стојан Новаковић (прир.), Законик Сеиефана Душана, Цара срӣской 1349. и 1354, Београд 1898, 223.

23 А. Соловјев, Законодавстиво, 198.

24 Анђелини (Angelini) наводи да је „кодификација Стефана Душана направила огроман корак напред у тачном одређивању кривичних дела и новчане казне која је са њима повезана“ („la codificazione di Stefan Dušan aveva compiuto un notevole passo in avanti nella precisa determinazione del crimine e della pena pecuniaria ad esso connessa") јер су у законику „одређене разне новчане казне за различита кривична дела према њиховој тежини“ („con la fissazione di un tariffario per $i$ vari reati, proporzionato alla gravità"). Код неких деликата су ипак казне зависиле од стале- 
Ова одредба представља допуну чл. 49 , која прописује одговорност крајишника за упад непријатељске војске коју он не би задржао на повратку из земље. Говори се о борби против разбојника, која представља дужност војводе-крајишника. ${ }^{25}$ Наиме, властела која је била дужна да чува границу, била је дужна и да је чува од разбојника. ${ }^{26}$ У овом члану се говори о разбојницима који би упали из друге државе у цареву државу ради плена. ${ }^{27}$ Одговорност је настајала само ако крајишник не би спречио излажење разбојника из државе, а не при њиховом улажењу у исту. ${ }^{28}$ Дакле, властелин - крајишник је увек морао да се брани (помоћу војника са својих имања) од туђе војске и разбојника, јер му је било запрећено новчаном казном. ${ }^{29}$

Чл. 145-150. представљају покушај борбе против разбојника и лопова.

У чл. $145 .{ }^{30}$ предвиђена је колективна одговорност ${ }^{31}$ села за случај скривања разбојника у селу. Циљ норме је била елиминација професионалних крадљиваца и разбојника због учесталости вршења ових кривичних дела. ${ }^{32}$ Како каже Тарановски, „није ту у питању само де-

шке припадности учиниоца дела. Paolo Angelini, „Linfluenza del Diritto Criminale

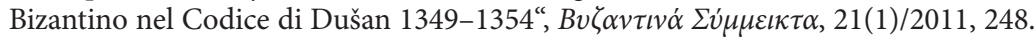

25 А. Соловјев, Законик Цара Сйефана Душана 1349. и 1354. іоgине, Српска академија наука и уметности, Београд 1980, 282.

26 С. Новаковић, 231-232.

27 Ђ. Бубало, 204.

28 А. Соловјев, Законик, 282.

29 Т. Тарановски, 35.

30 „Заповеда царство ми: По свима земљама, и по градовима, и по жупама и по крајиштима лопова и разбојника да није ни у чијем пределу. И овим начином да се укине крађа и разбојништво; У којем се селу нађе лопов или разбојник, то село да се распе, а разбојник да се стрмоглав обеси, а лопов да се ослепи, а господар села тога да се доведе свезан царству ми, да плаћа све што је учинио разбојник или лопов од почетка, и опет да се казни као лопов и разбојник.“

31 Институт колективне одговорности потиче из старог српског обичајног права (када се напад на особу из заједнице схватао као напад на целу заједницу, а и појединац је био схваћен као представник своје заједнице). Ипак, колективна одговорност се у Душановом законику јавља знатно ређе, јер је предвиђена „само у одређеним случајевима изричито предвиђеним законику“ („solamente a determinate fattispecie espressamente previste nel codice"), док се за већину деликата одговара на основу индивидуалне одговорности. P. Angelini, „L'influenza“, 227; P. Angelini, „The Code of Dušan 1349-1354“, Tijdschrift voor Rechtsgeschiedenis / Revue d'Histoire du Droit / The Legal History Review, Vol. 80, 1-2/2012, 90; Драгош Јевтић, Драгољуб Поповић, Нароgна иравна исӣорија, Универзитет у Београду - Правни факултет, Београд 2015, 79.

32 А. Соловјев, Законик, 294; Ђ. Бубало, 205. 
кларација кривичне забране, него и проглас борбе на уништавање“ лопова и разбојника. ${ }^{33}$ Опште јемство је управо „најјаче средство којим се Душаново законодавство служи против многих гусара“. 34 Оваква одредба је донета зато што је државни апарат средњовековних држава био скроман, па је због тога и у српској држави у средњем веку наметнуто органима власти територијалних заједница и самим територијалним заједницама да воде генералну истрагу. ${ }^{35}$ Истрага се спроводила тако што би се на збору локалних становника саслушали учесници, који су били у обавези да именују познате лопове и разбојнике. Долазило би до гласања, па би се једногласно или већином гласова одредило ко су професионални лопови и разбојници, а они би се предали државној власти која би их казнила. ${ }^{36}$ То значи да су се судије „царства ми“37 ослањале на истрагу спроведену у селима, a, само изузетно, овај поступак су могле покренути и судије „царства ми“, у случају да неки професионални лопов или разбојник не би био предат власти, него би након тога био откривен у том селу. ${ }^{38}$ Потреба за општом истрагом се јавља јер су разбојници угрожавали саобраћај и промет тако што су нападали трговце и путнике, па је било потребно не само да се учиниоци дела казне, него и да се разбојништво као појава сасвим уклони. ${ }^{39}$ И разбојник и господар села би били кажњавани смрћу, а господар села би био и у обавези да надокнади сву штету, што показује да су феудални господари били најодговорнији кад би се у селу нашао професионални разбојник или лопов. ${ }^{40}$ Дакле, они би били кажњавани строже од разбојника у случају немара и неизвршавања обавезе опште истраге. ${ }^{41}$ Појам „господари“

33 Т. Тарановски, 296.

34 А. Соловјев, Законодавстиво, 198.

35 Нина Кршљанин, „Колективна одговорност у Душановом законику“, Слободан Перовић (ур.), Правни живот̄, 10/2011, том 2, 418; Биљана Марковић, „Разбојништво“, ЛССВ, Београд 1999, 621.

36 Т. Тарановски, 569-570.

37 Термин судије „царства ми“ се користи само у чл. 139. и 148, а у чл. 157. и 161. се користи и термин „судије цареви“. Зоран Мирковић, „Судије 'царства ми' Душановог законика“, Сима Ћирковић, Коста Чавошки (ур.), Законик иара Сиеефана Душана: зборник раgова са научноі скуйа одржаної у САНУ 3. окйобра 2000, йовоgом 650 іолина оg ирроїлашена Законика цара Сйебана Душана, Београд 2005, 24.

38 Зоран Чворовић, Душанов законик у руском оїлеgалу, Catena Mundi, Београд 2018, 94-97.

39 Т. Тарановски, 352.

40 А. Соловјев, Законик, 295; Ђ. Бубало, 205.

41 3. Мирковић, Срйска йравна исйорија, Универзитет у Београду - Правни факултет, Београд 2017, 70. 
треба тумачити као „имаоци који су у селу седели и селом својим сами управљали“. 42 Напослетку, село се кажњавало конфискацијом и расељавањем. ${ }^{43}$

Прописано је да би на исти начин били кажњавани „и кнезови, и примићури, и владалци, и престојници, и челници, који се налазе управљајући селима и катунима“ (...), „ако се нађе код њих лопов или разбојник“ (чл. 146). Према Новаковићу, кнезови су „сеоске и катунске старешине по северозападним странама, даље од утицаја грчкога“, а примићури су исто то, али „у крајевима ближе са Грцима“.4 Радојчић говори да је „примићур пастирски поглавица“, 45 а Бубало га дефинише као „старешину влашког катуна“.46 Владалац је управни чиновник који се налазио у властеоским или црквеним селима. ${ }^{47}$ Престојник је био „надзорни орган на властелинству“, а челник је појам који се користио за све управнике (од управника са двора до управника на манастирском имању). ${ }^{48}$ Дакле, у овом члану се говори о одговорности ${ }^{49}$ унутрашње администрације властелинстава, јер би владаоци одговарали пред државом у случају нерада. ${ }^{50}$

Иста казна као она предвиђена за разбојнике и лопове предвиђена је за господаре у случају када су „владалци известили господаре, а господари се направили као да не знају“ (чл. 147). Овај члан се односи на властелу која је управљала селом. ${ }^{51}$ То значи да „владалци“ не би одговарали за ситуацију предвиђену у претходном члану уколико би извршили обавезу извештавања господара о разбојницима и лоповима, а господари не би узели у обзир извештаје. Тада би одговарали само господари. ${ }^{52}$

Законик даље говори о судском поступку против професионалних разбојника и лопова: „Судије, које царство ми постави по земљама да суде, ако пишу за шта било, за разбојника и лопове, или за које било судско решење, те пренебрегне писмо судије царства ми, или црква, или властелин, или који било човек, ти сви да се осуде као не-

42 С. Новаковић, 233-234.

43 Т. Тарановски, 350.

44 С. Новаковић, 233.

45 Н. Радојчић, 128-129.

46 Ђ. Бубало, 205.

47 С. Новаковић, 233.

48 Ђ. Бубало, 205.

49 Бубало говори о „командној одговорности“. Вид. ibid.

50 Т. Тарановски, 216.

51 А. Соловјев, Законик, 295.

52 Т. Тарановски, 216; Ђ. Бубало, 206. 
послушници царства ми“ (чл. 148). Сви (црква, властелини и сваки други човек) су морали да извршавају судске наредбе о разбојницима и лоповима (које су имале општеобавезни карактер) или би били кажњавани као „непослушници“:53 То значи да би били кажњавани као и у случају да нису послушали царску заповест. ${ }^{54}$

Следи одредба о поступку и доказивању у случају хватања разбојника на делу. „Овим начином да се казни лопов и разбојник доказани. И овакво је доказивање: Ако се само лице ухвати у њих, или ако их ухвате у разбојништву или крађи, или их преда жупа или села, или господари, или властела, који су над њима, како је више уписано, ти разбојници и лопови да се не помилују, него да се ослепе и обеce“ (чл. 149). „Лице“ се сматрало најважнијим, најјачим доказом. Под овим појмом су се подразумевали и осумњичени код кога би се нашла украдена ствар, и сама украдена ствар. ${ }^{55}$ Другим речима, појам „лице“ не представља само особу, већ и corpus delicti код крађе. ${ }^{56}$ Правила се разлика између разбојника (или лопова) ухваћених на делу и разбојника (или лопова) који нису ухваћени на делу. ${ }^{57}$ Законодавац у изворном тексту користи термин „обличеније“ које је означавало хватање на делу. ${ }^{58}$ Разбојник ухваћен на делу је онај разбојник код кога је нађена украдена ствар, који је лично ухваћен у току извршења дела и онај који је предат жупи, селу, господару или властелину. ${ }^{59}$ Доказна средства у овом случају су проналазак украдене ствари код осумњиченог, хватање учиниоца на делу и општа истрага. ${ }^{60} 3 \mathrm{a}$ разбојника ухваћеног на делу је била прописана смртна казна без могућности помиловања: био би обешен, а његово тело остављено да виси. ${ }^{61}$ Немогућност помиловања се није односила на помиловање учињено од стране владаоца, већ на оно учињено од стране странке која је разбојника (или лопова) ухватила, а које се огледа у пуштању,

53 А. Соловјев, Законик, 296; Ђ. Бубало, 206.

54 С. Новаковић, 234-235. Вид. чл. 136.

55 Б. Марковић, „Поличје, лице“, ЛССВ, Београд 1999, 547.

56 А. Соловјев, Законик, 296.

57 3. Мирковић, Срӣска, 69-70.

58 Законодавац не прави разлику између обличног лопова и разбојника. Д. Јевтић, Д. Поповић, 85.

59 Б. Марковић, „Поличје, лице“, 547; С. Новаковић, 235; Ђ. Бубало, 207.

60 Као доказно средство против професионалних лопова и разбојника се не јавља оптужба трећег лица изнућена тортуром, јер српско средњовековно право не познаје тортуру (3. Чворовић, 99-103).

61 3. Мирковић, Срйска, 69-70. Занимљиво је навести да се смртна казна изрицала чешће за имовинска кривична дела него за убиство. Срђан Шаркић, „Казне“, ЛССВ, Београд 1999, 269-270. 
односно мирењу ${ }^{62}$ Уколико би се „лице“ нашло код оптуженог након што би оптужени био оправдан на суду, казнили би се они поротници који су кривца оправдали. ${ }^{63}$ Треба напоменути да се није правила разлика између припадника различитих сталежа. Иако су у српској држави постојали сталежи, услед чега је постојала сталешка неједнакост у разним гранама права (у начелу се о томе водило рачуна и у кривичном праву), ${ }^{64}$ у погледу неких кривичних дела у која спада и разбојништво, припадници различитих сталежа су исто кажњавани. Разлог за то јесте што се разбојништвом бавила и властела. ${ }^{65}$ Питање је, међутим, колико су ове одредбе у пракси заиста спровођене, јер постоје примери који показују да је разбојништво најчешће кажњавано новчаном казном, а не смрћу, попут пресуде коју је донео лично цар Душан, у којој је је плаћена новчана казна за разбојништво праћено тучом на хиландарској земљи. ${ }^{66}$

У случају непостојања правог доказа, било је предвиђено правдање железом, односно посебним обликом Божјег суда, које је прописано у чл. $150 .{ }^{67}$ Оно се састојало у томе што би оптужени носио од црквених врата до олтара, и положио на олтар, усијано железо које је извадио из ватре. ${ }^{68}$ Ако би ране зарасле после одређеног времена, то је значило да је он себе оправдао. У супротном би се сматрало да је крив. ${ }^{69}$ За разлику од претходног члана, овде је предвићена могућност помиловања. ${ }^{70}$ Није ни изричито прописана казна, па је Тарановски

62 Најчешћи начин извршења кривичног дела игнорисања судијине пресуде у пракси је управо било кршење забране мирења. 3. Чворовић, 105-109.

63 Б. Марковић, „Поличје, лице“, ЛССВ, 548.

64 Примера ради, правила се разлика према учиниоцу кривичног дела, односно нека кривична дела су могла учинити само припадници одређеног сталежа. Код већине кривичних дела која су могла учинити припадници свих сталежа, Законик прописује строже новчане казне за властелу, како би се обезбедила економска једнакост између властеле и нижих сталежа, али је властела изузета од телесног кажњавања, осим у случају вршења најтежих кривичних дела. Вид. Н. Кршљанин, „Сталешка неједнакост у казненом праву Душановог законика“, Сйрани йравни животи, 3/2012, 41 и даље.

65 Т. Тарановски, 280, 353.

66 3. Мирковић, „Византијски утицаји на кривично право у средњовековној Србији - погледи Теодора Тарановског и Александра Соловјева“, 3. Мирковић, Н. Кршљанин (ур.), Зборник раgова 125 іодина оg рођена Александра Васиљевича Соловјева, Правни факултет Универзитета у Београду, Београд 2016, 161-162.

67 „И ако ко потера судом разбојника и лопова, а не буде доказа, да им је оправдање железо, што је одредило царство ми, да га узимају на вратима црквеним из огња, и да га постави на светој трпези“.

68 Не постоје подаци који говоре о примени ове одредбе у пракси. С. Ћирковић, „Божји суд“, ЛССВ, Београд 1999, 53.

69 3. Мирковић, Срйска, 69-70.

70 3. Чворовић, 105. 
дошао до ње посредним путем, преко чл. $116 .^{71}$ Он је закључио да је обични разбојник морао да плати глобу у износу вишеструке вредности украдене ствари. ${ }^{72}$ Према Тарановском, ова одредба се није односила на „обичне“ лопове и разбојнике (обично разбојништво се састојало у појединачном одузимању туђе ствари), већ само на професионалне и на оне ухваћене на делу. Он наводи да је за спорове о разбојништву и о другим тешким кривичним делима био надлежан државни суд (царски дугови или резервата), ${ }^{73}$ при чему се поступак покретао по службеној дужности у случају професионалних разбојника и лопова, а по приватној тужби у случају обичних разбојника и лопова. ${ }^{74}$ Чворовић сматра да је тумачење Тарановског погрешно и да не би требало раздвајати професионалне и „обличне“ лопове и разбојнике, јер, према Чворовићу, анализирани чланови праве разлику „према критеријумима доказног средства и забране мирења“, па би било оправдано правити разлику између обичне крађе и обичног разбојништва и „обличне“ крађе и „обличног“ разбојништва. ${ }^{75}$ Чл. 150. је последња одредба из новеле о разбојницима и лоповима. ${ }^{76}$

Чл. 157-160. су посвећени заштити путника од разбојника и лопова, дужностима да се путеви чувају, и разним накнадама штете до којих би дошло у случају кршења ових обавеза. ${ }^{77}$

Прописана је дужност кефалија 78 да поставе стражу која би чувала путеве од разбојника и лопова (чл. 157). ${ }^{79}$ Уколико би ипак до-

71 „Ко што нађе у царевој земљи, да не узме, те да не рекне, вратићу, ако ко позна, ако ли прихвати, или узме, да плати као тат или разбојник, а што нађе у туђој земљи, на војсци, да носи пред цара и војводу“.

72 Т. Тарановски, 350. Претпоставља се да су ове казне уређене правилима обичајног права и да су оне биле познате свима, што нас доводи до закључка да је фактички (иако не и формално) постојао правни дуализам. Вид. Никола Ф. Павковић, „Обичајно право“, ЛССВ, Београд 1999, 455-457.

73 За најтежа дела судио је лично владар који се сматрао највишим судијом. (3. Мирковић, Срйска, 71.) Ипак, на основу чл. 145. и 148, може се закључити да би у пракси, по правилу, органи локалне заједнице морали да иницирају поступак против професионалних лопова и разбојника. (3. Чворовић, 93.)

74 Т. Тарановски, 272-277, 350-352.

75 3. Чворовић, 109-110. Може се закључити да Тарановски прихвата тродеобну поделу на „облично“ разбојништво, професионално разбојништво и обично разбојништво, док Чворовић прихвата дводеобну поделу на „облично“ разбојништво и обично разбојништво.

76 А. Соловјев, Законик, 296.

77 С. Новаковић, 243.

78 Кефалије су капетани, односно главари градова. (Ibid., 240.)

79 „Где се налазе жупе смесне, села црквена и царева, и властеоска, и буду смесна села, и не буде над том жупом једнога господара, него ако буду кефалије и судије цареви, које је поставио цар, да поставе страже по свим путовима, и ке- 
шло до напада, кефалије су биле дужне да плате штету оштећеном из сопствене имовине. Свој трошак су наплаћивали од стражара који су несавесно вршили своје обавезе, и од самих разбојника и лопова у случају да су ухваћени. ${ }^{80}$ Села која се помињу нису само „властеоска“ и „царева“, већ и црквена, односно црквена села „не само да се тога не ослобођавају, него се чак спомињу поред села владаочевих и властеоских “81. С обзиром на чињеницу да су кефалије плаћале само новчану суму, може се закључити да је њихова одговорност била грађанска, а не кривична. ${ }^{82}$

Чување страже је предвиђено и за села која су се налазила око напуштених брда: „Ако је пусто брдо међу жупама, села околна, која су око тога брда, да чувају стражу, аколи не ушчувају стражу, што се учини у том брду, у пустоши штета или разбојништво, или крађа или које зло, да плаћају околна села, којима је речено чувати пут“ (чл. 158). Уколико би дошло до штете, село је било колективно одговорно за њу. ${ }^{83}$ Овај члан представља нову врсту општег јемства коју је увео Душанов законик. ${ }^{84}$

Несметано путовање трговаца кроз Србију је било обезбеђено још једном нормом. „Купци, који пролазе ноћу, на ноћиште где дођу, ако их не припусти владалац или господар села тога, да преноће у селу купци, по закону цареву, како је у законику, ако што изгуби путник, онај господар, и владалац и село све да плате, јер их нису у село пустили" (чл. 159). Треба напоменути да Призренски препис Душановог законика не садржи речи „у селу“, док их садрже сви преписи старије редакције. Додатак се састоји у томе што би село одговарало у случају да у селу нису присутни господар и управник. ${ }^{85}$ Објашњење ове норме се састоји у томе што је обавеза предвиђена за село, а владалац има улогу „заступника колектива“" 86 На основу овог члана, село, односно управитељи села и господари, били су у обавези да обезбеде преноћиште трговцима и другим путницима. Уколико би путник претрпео штету због ноћења ван села јер му нису пружени преноћиште и заштита у селу, претрпљену штету су били у обавези

фалијама да предаду путове, и да их чувају са стражама, и да, ако се ко опљачка или покраде, или се које зло учини, тај час иду кефалијама, да им плаћају од свога, а кефалије страже да траже и разбојнике и лопове“.

80 А. Соловјев, Законик, 303; Ђ. Бубало, 209.

81 Т. Тарановски, 95.

82 Ibid., 388.

83 Ђ. Бубало, 210.

84 С. Новаковић, 241-242.

85 А. Соловјев, Законик, 304.

86 Н. Кршљанин, „Колективна одговорност“, 423. 
да надокнаде управитељ, господар, и село. Законик не наводи изричито како је одговорност за штету подељена. ${ }^{87}$

Функцију заштите трговаца и калуђера има и чл. $160{ }^{88}$ Сваког покраденог трговца (без обзира на то да ли је над њим учињена крађа или разбојништво) исплатио би лично владар, који је после могао да тражи накнаду штете од кефалија и од властелинових жупских господара, који су били у обавези да организују чување страже на путевима. ${ }^{89}$ Заправо, овде се ради о два различита члана, па их преписи Атонске групе раздвајају. Међутим, они су овде наведени у истом члану јер је то случај у Струшком и Призренском препису. ${ }^{90}$ Први део члана (односно први члан) је омогућавао трговцима да се обрате цару ради накнаде штете, и цару да се наплати од кефалија и од властелинових жупских господара. Други део члана (односно други члан) говори о потребним условима за примену овог члана. Било је потребно да се путник, трговац или Латинин јави првим стражама са целокупном својом имовином, коју би страже предавале једна другој. Уколико би се нешто изгубило, кефалије и стражари су били у обавези да надокнаде штету, што нам показује да је, у пракси, могућност цара да одговара својом имовином предвиђена само на папиру. ${ }^{91}$ За време Царства, одговорност владара је била примарна. Пре 92 и након тог времена, она је била супсидијарна: владар би морао да плати трговцима само ако им село, жупа и околина не би надокнадили штету. ${ }^{93}$

Разбојништво се у Раковачком препису спомиње у чл. 191: „И ако разбојник украде свиње цареве, да плати околина, аколи се украду свиње, да се суди свињар са жупом, па што рекне суд“. Говори се о одговорности околних села за штету коју би цар претрпео

87 Ђ. Бубало, 210.

88 „Ако се где догоди којему било госту, или трговцу, или калуђеру, те му узме што разбојник или лопов, или која год сметња, да иду ти сви цару, да им плати цар, што буду изгубили, а цар да тражи кефалије и властелу, којима буде пут предан и страже предане. И сваки гост, и трговац, и Латинин да доходи првим стражама са свим што има и носи, да га провађају, и стража стражи да га предаје са свим; аколи се догоди, те што изгубе, да им је порота веродостојни људи, што рекну по души да су изгубили, с оним поротницима, то да им плате кефалија и стража“.

89 А. Соловјев, Законик, 304.

90 С. Новаковић, 243.

91 Ibid.

92 Краљ Милутин је 1308. године дао Дубровчанима трговачке повластице гарантујући за њихову имовину и предвидевши колективну одговорност села за штету у њему учињену. У случају да село не би платило, платило би „краљевство ми“. Б. Марковић, „Разбојништво“, 611.

93 Ђ. Бубало, 211. 
крађом свиња. Суд би у сваком конкретном случају утврдио ко је био одговоран између свињара и господара жупе за боравак и учињено кривично дело у жупи..$^{94}$ Суђење разбојнику за крађу царевих свиња, односно суђење свињара са жупом у случају крађе свиња је било у надлежности судија „царства ми“.95

\section{4. ТЕЖИНА КАЗНЕ И ФАКТОРИ КОЈИ СУ УТИЦАЛИ НА ЊУ}

Поставља се питање „применом којег логичког принципа можемо одредити да ли ће казна (за одређено кривично дело) бити смрт, сакаћење или затвор"). ${ }^{96}$ Заправо, логика ни не постоји јер нема логичке везе између кривичног дела и казне која је предвиђена за учиниоца кривичног дела, па одговор на то треба тражити у духу времена, зато што је управо „дух времена тај који одређује врсту и дужину казне " (,it is the temper of the times that determines the character and extent of punishment"). ${ }^{97}$

Могло би се рећи да је на тежину кажњавања утицало неколико фактора. Пре свега, важан фактор представља утицај византијског права. Оно је утицало на српско право на три начина: најпре, многи византијски правни зборници су преведени на српски језик и примењени у српској држави. Даље, прихваћени су разни институти римског права преко грчких превода, а не изворних латинских текстова. Напослетку, унети су многи чланови из византијских кодификација у српске (око 60 чланова Душановог законика је преузето из византијских извора). ${ }^{98}$ Ипак, ни у Прохирону из којег су преузете казне, лопов ухваћен на делу није кажњаван смрћу, већ одсецањем руке, што значи да су прописане строже санкције у српском средњовековном праву у односу на византијско. ${ }^{99}$ Као што је већ напоменуто, још једно одступање од византијског права јесте колективна одговорност села, која је преузета из српског обичајног права, а није постојала у византијском. ${ }^{100}$

94 Ibid., 221.

95 3. Мирковић, „Судије“, 29.

96 „What principle of logic can determine whether the punishment shall be death, mutilation or imprisonment?"“. V. Bar, Introduction by E. Keedy, I.

97 Ibid.

98 Срђан Шаркић, „Утицај византијског права на средњовековно српско право“, Slověne, International Journal of Slavic Studies, Vol. 4, 2/2015, 120.

99 Т. Тарановски, 310.

100 P. Angelini, „The Code“, 90. 
Хришћанство је имало одређен утицај на начин кажњавања, јер телесне и смртне казне, поготово оне које су извршаване на бруталан начин, проузрокујући озбиљну бол, нису схватане само као санкција, већ и као могућност да се учинилац најтежих кривичних дела за њих искупи. „Болна и брутална смрт је могла, сама по себи, да представља пут ка спасењу“" (a painful and brutal death could, on its own, constitute a pathway to salvation). ${ }^{101}$ Дакле, бол је био „благослов од Бога“ ( $a$ blessing from God), jep је тако учиниоцу кривичног дела било омогућено да очисти своју душу и да се искупи за своје грехове у овом животу, а не у следећем. ${ }^{102}$ Интересантно је да су и у исламском праву за разбојнике прописане строге казне, које су ишле од одсецања рука и ногу, преко прогонства, до смртне казне. ${ }^{103}$

Трећи разлог који оправдава строгост кажњавања јесте тај што казна почиње да се схвата као средство које би људе одвратило од чињења кривичних дела. Другим речима, генерална превенција, заједно са специјалном, постаје циљ кажњавања. ${ }^{104}$ Учинилац се кажњава да остали не би чинили исто. С обзиром на циљ, „што је ужаснија казна, то је боље њено дејство“. ${ }^{105}$ Овај начин кажњавања је јако критикован од стране неких аутора. Примера ради, Томас Мор (Thomas More) истиче да смртна казна у целој Европи у средњем веку „не доприноси искорењивању разбојништва“ зато што „не решава проблеме који настају првобитном акумулацијом капитала, а који

101 Sarah Tarlow, Emma Battell Lowman, Harnessing the Power of the Criminal Corpse, Palgrave Macmillan, Leicester 2018, 41.

102 Ibid.

103 У случају одузимања новца и убијања жртве, предвиђено је распеће; у случају претње и одузимања новца без убијања другог лица, предвиђена казна је одсецање руке и ноге; ако разбојник убије жртву без узимања новца биће погубљен; ако прети невиним људима, али их не убије, кажњава се прогонством. Вид. Сура 5:33: „Казна за оне који против Алаха и Посланика Његова војују и који неред на земљи чине јесте: да буду убијени, или разапети, или да им се унакрст руке и ноге одсијеку или да се из земље прогнају. То им је понижење на овом свијету, а на оном свијету чека их патња велика“. Иначе, разбојништво је једно од пет кривичних дела која је прописао Кур’ан, а може да уђе у Џенет само онај ко се чува туђе имовине јер се, према Суни, туђа имовина сматра пороком. Etim E. Okon, „Hudud punishments in Islamic criminal law“, European Scientific Journal, Vol. 10, 14/2014, 234; В. Станимировић, Хрестиоматиија за уйореgну ӣравну йраgищију, Универзитет у Београду - Правни факултет, Београд 2012, 243-245; . Аврамовић, В. Станимировић, 193;

104 Б. Марковић, „Разбојништво“, 612.

105 „The more horrible the punishment, the greater its salutary effect”. Albert W. Stearns, "Evolution of Punishment", Journal of Criminal Law and Criminology, Vol. 27, 2/1936, 223-224. 
су прави узрок разбојништва и свеопштег осиромашења сељака и најамника“. Дакле, према Мору, смртна казна „потиче из површног или чак никаквог увида у економску и социјалну ситуацију“. 106

У сваком случају, начин кажњавања у Душановом законику је у складу са начином кажњавања у средњем веку у другим државама. У великој већини осталих држава средњег века разбојници су кажњавани смрћу. Примера ради, у средњовековној Енглеској је поред смртне казне прописана и казна конфискације имовине. ${ }^{107}$ Неки законици ипак нису овако строги, па је, према Салијском законику, код Франака, за разбојнике прописана новчана казна. ${ }^{108}$

Коначно, смртна казна представља легитимну врсту казне у овом периоду, јер се мора чекати половина XX века, када је дошло до развоја људских права и слобода грађанина, да се ова казна махом укине. Најзначајнија конвенција у којој се штите права човека јесте Конвенција за заштиту људских права и основних слобода (Европска конвенција о људским правима) ${ }^{109}$ из 1950. године, у којој је зајемчено право на живот (чл. 2). ${ }^{110}$ То значи да је смртна казна у средњем веку легитимна казна, јер је она у Европи тек ограничена

106 Tomas Mor, Utopija, prevod Franjo Barišić, Utopija, Beograd 2002, 8-9. Што се тиче могућих алтернатива, у средњем веку се јавља и казна затвора, па се може поставити питање да ли би било боље да су разбојници били кажњавани том казном. Стојановић сматра да је казна затвора постала ефикасна тек у XIX веку, јер она захтева испуњење неколико услова да би функционисала. Пре свега, захтева се постојање јаких државних органа. Затим, оно што је неопходно јесте и велико богатство државе зато што је казна затвора веома скупа кривична санкција. Због тога Стојановић говори да су „судије раније празниле затворе, а данас их пуне“ јер се раније казна затвора користила најчешће као привремена казна за учиниоца, како би се се обезбедило његово присуство у судском постпуку, на крају кога би му се изрекла друга казна. 3. Стојановић, Кривично ирраво, 299.

107 С. Аврамовић, В. Станимировић, 230.

108 У износу од 2500 динара или 62.5 солида, односно 1200 динара или 30 солида у зависности од тога да ли је кривично дело учињено над обичним човеком или над робом. Вид. В. Станимировић, 266-275.

109 Конвенцију у складу са Протоколом 11 („Сл. листи СЦГ-Међунароgни уі̄овори“, бр. 9/2003, 5/2005 и 7/2005 - испр. и „Сл. іласник РС - Међународни уіовори“, бр. 12/2010 и 10/2015) потписала је и ратификовала и државна заједница Србија и Црна Гора, као и све остале земље Европе, изузевши Белорусију. Steven Greer, „What's Wrong with the European Convention on Human Rights?", Human Rights Quarterly, Vol. 30, 3/2008, 680.

110 Војин Димитријевић, „Конвенција за заштиту људских права и основних слобода (Европска конвенција о људским правима) од 4. новембра 1950.“, О йраву и нейраву, Фабрика књига, Београд 2011, 42-43. 
Шестим протоколом уз Европску конвенцију о људским правима, ${ }^{111}$ а у потпуности укинута Тринаестим протоколом. ${ }^{112}$

\section{5. ЗАКЉУЧАК}

Рад покушава да одговори на три основна питања: како је кривично дело разбојништва било уређено у Душановом законику, каква је казнена политика за кривично дело разбојништва, и који су разлози заступања овакве казнене политике.

У погледу првог питања, може се рећи да је схватање разбојништва у Душановом законику прилично различито од схватања овог кривичног дела данас. Највећа разлика јесте што су се тада изједначавале различите врсте разбојништва са истим врстама крађе: са једне стране „облично“ разбојништво и крађа, са друге обично (према Тарановском и професионално). Данас, разбојништво и крађа се знатно разликују у зависности од тога да ли се одузимање туђе ствари врши употребом принуде или не. У том смислу се може закључити да је сличније данашњем времену решење заступано у Скраћеној синтагми, према којој разбојништво представља крађу извршену употребом силе.

У погледу другог и трећег питања, може се рећи да се доста блажи начин кажњавања који је био прихваћен 1349. године није показао ефикасним, пре свега зато што је водио социјалној нестабилности. То је и разлог због којег се разбојништво касније кажњавало без обзира на сталешку припадност, како се не би реметило социјално стање у држави. Управо из овог разлога је у допунама Душановог законика из 1354. казнена политика немилосрдна, па чак и окрутнија у односу на византијску. На питање због чега су усвојена таква решења, може се закључити да су хришћански морал, гарантовање својине и покушај да се искорене појаве разбојништва и крађе утицали на цео Душанов законик (и на целокупну Душанову законодавну делатност).

111 „Смртна казна се укида. Нико не може осудити на смртну казну или погубити.“ (чл. 1). „Држава може у свом законодавству да предвиди смртну казну за дела извршена у доба рата или непосредне ратне опасности; таква казна примениће се само у случајевима предвиђеним законом и у складу с његовим одредбама. Држава обавештава генералног секретара Савета Европе о релевантним одредбама тог закона." (чл. 2).

112 „Смртна казна се укида. Нико не може осудити на смртну казну или погубити.“ (чл. 1). 
Коначно, остаје отворено питање да ли је цар Душан при регулисању кривичног дела разбојништва, са данашњег аспекта посматрано, за то време био напредни законодавац, односно да ли је много боље разумео потребе људи и њихове склоности ка опасном понашању, него што то данас може и да се замисли. Пре свега, чињеница да су се одредбе у Скраћеној синтагми примењивале безуспешно пет година указује на то да је Душан покушао и блажим решењима да умањи или потпуно отклони појаву разбојништва, али није било могуће постићи такав циљ на тај начин. Такође, кажњавање разбојника у Душановом законику је у складу са кажњавањем тог времена, јер се наилази на слична решења у другим правним системима тог тоба. С обзиром на наведене чињенице, сматрамо да се на ово питање може одговорити позитивно.

\section{БИБЛИОГРАФИЈА}

\section{ИЗВОРИ:}

Закон о ратификацији Европске конвенције за заштиту људских права и основних слобода, измењене у складу са Протоколом број 11, Протокола уз Конвенцију за заштиту људских права и основних слобода, Протокола број 4 уз Конвенцију за заштиту људских права и основних слобода којим се обезбеђују извесна права и слободе који нису укључени у Конвенцију и први Протокол уз њу, Протокола број 6 уз Конвенцију за заштиту људских права и основних слобода о укидању смртне казне, Протокола број 7 уз Конвенцију за заштиту људских права и основних слобода, Протокола број 12 уз Конвенцију за заштиту људских права и основних слобода и Протокола број 13 уз Конвенцију за заштиту људских права и основних слобода о укидању смртне казне у свим околностима - „Сл. листи СЦГ - Међунароgни уіовори“, бр. 9/2003, 5/2005 и 7/2005 - испр. и „Сл. іласник РС - Међунарояни уїовори“, бр. 12/2010 и 10/2015.

Ђорђе Бубало (прир.), Душанов законик, Завод за уџбенике / Службени гласник, Београд 2010.

Матија Властар, Синйаімма (са српскословенског језика превела Татјана Суботин-Голубовић), Српска академија наука и уметности, Београд 2013.

Стојан Новаковић (прир.), Законик Сиеефана Душана, Цара срӣскої 1349. и 1354, Београд 1898.

Никола Радојчић (прир.), Законик Цара Сиеебана и Душана 1349. и 1354, Српска академија наука и уметности, Београд 1960.

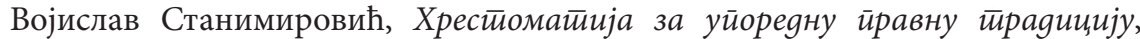
Универзитет у Београду - Правни факултет, Београд 2012. 


\section{ЛИТЕРАТУРА:}

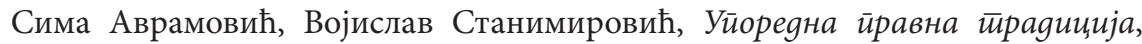
Универзитет у Београду - Правни факултет, Београд 2018.

Paolo Angelini, „L’influenza del Diritto Criminale Bizantino nel Codice di Dušan

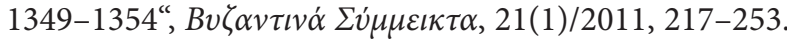

Paolo Angelini, „The Code of Dušan 1349-1354“, Tijdschrift voor Rechtsgeschiedenis / Revue d'Histoire du Droit / The Legal History Review, Vol. 80, 1-2/2012, 77-93.

Жика Бујуклић, Римско йривайно ӣраво, Универзитет у Београду - Правни факултет, Београд 2017.

Carl Ludwig von Bar et al., A History of Continental Criminal Law, Translated by Thomas S. Bell et al., The Continental Legal History Series., Little, Brown and Company, Boston, Massachusetts, US. 1916.

Steven Greer, „What's Wrong with the European Convention on Human Rights?", Human Rights Quarterly, Vol. 30, 3/2008, 680-702.

Војин Димитријевић, „Конвенција за заштиту људских права и основних слобода (Европска конвенција о људским правима) од 4. новембра 1950.“, О йраву и нейраву, Фабрика књига, Београд 2011, 38-47.

Јасмина Играчки, „Кривичноправни и криминолошки аспекти насиља и

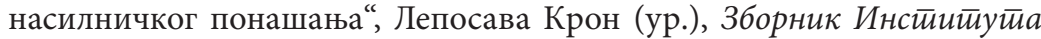
за криминолошка и социолошка истраживаюа, Година XXXIII/2014, Број 1, Институт за криминолошка и социолошка истраживања, Београд 2014, 137-148.

Bernard S. Jackson, „Some comparative legal history: robbery and brigandage“, Georgia Journal of International and Comparative Law, Vol. 1, 1/1970, 45-104.

Драгош Јевтић, Драгољуб Поповић, Нароgна йравна истиорија, Универзитет у Београду - Правни факултет, Београд 2015.

Нина Кршљанин, „Колективна одговорност у Душановом законику“, Слободан Перовић (ур.), Правни животе, 10/2011, том 2, 413-428.

Нина Кршљанин, „Сталешка неједнакост у казненом праву Душановог за-

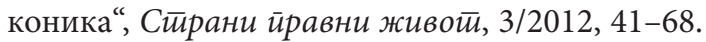

Ferdinand Mackeldey, Manuale di diritto romano contenente la teoria delle istitute preceduto da una introduzione allo studio del diritto romano, Prima traduzione italiana, Tipografia Pacini, Cardinali e C., R. Biblioteca di Cremona 1843.

Зоран Мирковић, „Византијски утицаји на кривично право у средњовековној Србији - погледи Теодора Тарановског и Александра Соловјева“, Зоран Мирковић, Нина Кршљанин (ур.), Зборник раgова 125 іоgина og рођена Алексанgра Васитевича Соловјева, Правни факултет Универзитета у Београду, Београд 2016, 153-161. 
Зоран Мирковић, Срйска ӣравна истиорија, Универзитет у Београду - Правни факултет, Београд 2017.

Зоран Мирковић, „Судије 'царства ми’ Душановог законика“, Сима Ћирковић, Коста Чавошки (ур.), Законик и,ара Сиеебана Душана: зборник раgова са научноі скуйа овржаноі̄ у САНУ 3. окйобра 2000, йоводом 650 іолина og ирроілашена Законика ияара Сиеефана Душана, Београд 2005, 21-36.

Tomas Mor, Utopija, prevod Franjo Barišić, Utopija, Beograd 2002.

Etim E. Okon, „Hudud punishments in Islamic criminal law“, European Scientific Journal, Vol. 10, 14/2014, 227-238.

Jonathan Rose, „Studying the Past: the Nature and Development of Legal History as an Academic Discipline“, The Journal of Legal History, Vol. 31, 2/2010, 101-128.

Marina M. Simović, Dragan Jovašević, „Imovinska krivična djela sa elementima nasilja i organizovanog kriminaliteta“, Miodrag N. Simović (ur.), Krivično zakonodavstvo i funkcionisanje pravne države, Srpsko udruženje za krivičnopravnu teoriju i praksu / Grad Trebinje / Ministarstvo pravde Republike Srpske, Trebinje 2018, 193-207.

Александар Соловјев, Законик Цара Сиеефана Душана 1349. и 1354. іолине, Српска академија наука и уметности, Београд 1980.

Александар Соловјев, Законоgавстиво Сиеебана Душана, Цара Срба и Грка, Београдски универзитет - Правни факултет, Београд 1928.

Albert W. Stearns, „Evolution of Punishment“, Journal of Criminal Law and Criminology, Vol. 27, 2/1936, 219-230.

Александар Стевановић, „Утицај економских фактора на настанак и развој организованог криминалитета“, Бранислава Кнежић, Ивана Стевановић, Јанко Међедовић (ур.), Зборник Инстичииуйа за криминолошка и социолошка истираживана, Година XXXVIII/2019, Број 1, Институт за криминолошка и социолошка истраживања, Београд 2019, 113-124.

Зоран Стојановић, Наташа Делић, Кривично йраво, Посебни gео (шесто допуњено издање), Правна књига, Београд 2019.

Зоран Стојановић, Кривично ӣраво, Ойитии gео (двадесет шесто допуњено издање), Правна књига, Београд 2019.

Зоран Стојановић, „Систем казни у кривичном праву Србије и потреба његовог даљег усавршавања“, Ђорђе Игњатовић (ур.), Казнена реакција y Србији, V део, Београд 2015, 1-24.

Dragomir Stojčević, „Gens, Consortium, Familia“, Studi in onore di Edoardo Volterra, Vol. 1, Milano 1971, 425-437.

Теодор Тарановски, Истиорија срӣскоі̄ иррава у Немағићкој gржави, Лирика, 2002. 
Sarah Tarlow, Emma Battell Lowman, Harnessing the Power of the Criminal Corpse, Palgrave Macmillan, Leicester 2018.

Сима Ћирковић, Раде Михаљчић (ур.), Лексикон срйскої Среgюеі века (ЛССВ), Београд 1999.

Зоран Чворовић, Душанов законик у руском оіллеgалу, Catena Mundi, Београд 2018.

Срђан Шаркић, „Утицај византијског права на средњовековно српско право“, Slověne, International Journal of Slavic Studies, Vol. 4, 2/2015, 106-118.

Милан Шкулић, „Англосаксонска доктрина „одбране замка“ у кривичном праву САД и њене могуће рефлексије на нужну одбрану у српском кривичном законодавству“, Ђорђе Игњатовић (ур.), Казнена реакција y Србији, VII део, Универзитет у Београду - Правни факултет, Београд 2017, 33-78. 


\title{
Andrej CONFALONIERI ${ }^{*}$
}

\section{ROBBERY IN DUŠAN'S CODE}

\begin{abstract}
Summary
When Dušan's Code was passed in 1349, only one robbery provision was included, because this crime was regulated by the abbreviated Syntagma of Matthew Blastares, so the legislator considered new provisions unnecessary. Nevertheless, the additions from 1354 paid great attention to the fight against robbers and thieves. The robbers caught in the act were punished with death penalty, while those who were not captured in an actual act of robbery were fined. In case there was a lack of evidence, a special form of divine judgment (justification by iron) was prescribed. The village was collectively responsible in case of hiding the robbers, in case the streets were not guarded and damage was caused to travellers, and in case someone stole the emperor's pigs. The duty to conduct a general inquiry into the masters, property managers, and elders was also foreseen, and they would be punished as robbers (and thieves) in the case of negligence and failure to comply with that obligation. Some provisions to protect traders and travellers from robbers and thieves were introduced (traders had the right to spend the night in the village and, in case of damage, the lord, the village and the ruler were responsible for the damage caused to them; the kephale had the duty to guard the streets). The paper attempts to determine the reasons for severe punishment for the crime of robbery, which can be the influence of Byzantine law, the acceptance of Christianity (pain represents the possibility for the sinner to redeem his sins) and the new general preventive purpose of punishment.
\end{abstract}

Key words: Robbery. - Dušan's Code. - Collective responsibility. - Death penalty. Medieval Serbia.

Рад приспео / Paper received: 17.4.2020. Измењена верзија / Revised version: 30.5.2020. Прихваћен за објављивање / Accepted for publication: 9.8.2020.

\footnotetext{
* The author is a second-year student at the University of Belgrade Faculty of Law, andrej.confalonieri@gmail.com
} 